\title{
The Dilemma of Ottoman Ex-Soldiers: Returning Home or Entering a New War*
}

\section{Osmanlı’nın Son Askerlerinin İkilemi: Eve Dönüş veya Yeni Bir Savaşa Giriş}

\author{
Murat YOLUN* ${ }^{* *}$
}

"This article is a revised and expanded version of the unpublished paper "Ottoman Ex-Soldiers: Returning Home or Going to a New War" presented at Post-War Transitions in Europe: Politics, States and Veterans, 19181923 on 28-30 March 2019.

"Assist. Prof., Adiyaman University, Faculty of Arts and Sciences, Department of History, Adiyaman, Turkey

ORCID: M.Y. 0000-0002-9881-0946

\section{Corresponding author/Sorumlu yazar:} Murat Yolun,

Adiyaman University, Faculty of Arts and Sciences, Department of History,

Adiyaman, Turkey

E-mail/E-posta: muratyolun@gmail.com

Submitted/Başvuru: 03.05.2021 Revision Requested/Revizyon Talebi: 06.06.2021

Last Revision Received/Son Revizyon: 04.11.2021

Accepted/Kabul: 04.11.2021

Citation/Atıf: Yolun, Murat. "The Dilemma of Ottoman Ex-Soldiers: Returning Home or Entering a New War." Yakın Dönem Türkiye Araştırmaları-Recent Period Turkish Studies 40 (2021): 115-134.

https://doi.org/10.26650/YTA2021-931971

\begin{abstract}
The armistice of Mudros, signed by the Ottoman Empire and the Allies, ironically brought about optimism and deep sadness among Ottomans. Soldiers and civilians wished that the Armistice would have heralded a peaceful period for the Empire that had experienced warfare since the Balkan Wars. However, the Ottoman soldiers had to choose whether to return to civilian life or resist the Allies' occupation. Many veterans looked forward to restarting their civil lives, even though some high-ranking officers looked for ways to save their homes from invasion. The latter thought that the Allies were disrespectful to the articles in the armistice of Mudros or violated them. Thus, some of the Ottoman commanders postponed the demobilization of the army for the preparation of a post-war resistance. The self-narrated documents of soldiers', especially the ones belonging to low-ranking soldiers, proved their reluctance for a new war due to their physical and psychological exhaustion. After all, many veterans desired to continue their lives as if nothing had happened in the Empire.
\end{abstract}

Keywords: First World War, Ottoman Empire, Demobilization, Ottoman Army, Turkish War of Independence

ÖZ

Osmanlı İmparatorluğu ile İtilaf Devletlerinin imzaladığı Mondros Mütarekesi, Osmanlılar arasında ironik bir şekilde hem iyimserlik havasına hem de derin bir üzüntüye sebebiyet verdi. Askerler ve siviller bu ateşkesin Balkan Savaşlarından bu yana savaş havası içinde yaşayan imparatorluk için barışçıl bir dönemin habercisi olmasını arzuladılar; ancak Osmanlı subayları, sivil hayata geri dönmek veya İtilaf Devletlerinin başlattığı işgallere karşı direnmek arasında bir tercih yapmak zorunda kaldılar. Bazı üst düzey subaylar, imparatorluğu işgallerden kurtarmanın yollarını ararken pek çok eski asker, sivil yaşama dönmeyi dört gözle bekliyordu. Osmanlı ordusunun yüksek rütbeli subayları Müttefiklerin Mondros'taki maddeleri ihlal ya da tahrif ettiğini düşünüyorlardı. Bu yüzden savaş sonrası direniş hazırlığı için ordunun terhisini durdurdular ya da ertelediler. Askerlerin ben anlatıları, özellikle düşük rütbedeki askerlerin fiziksel ve psikolojik yorgunluk nedeniyle yeni bir savaş için isteksiz olduğunu ortaya koymaktadır. Neticede birçok eski asker, hayatını imparatorlukta hiçbir şey olmamış gibi sürdürmek istemiştir.

Anahtar Kelimeler: Birinci Dünya Savaşı, Osmanlı Devleti, Terhis, Osmanlı Ordusu, Kurtuluş Savaşı 


\section{Introduction}

The Ottoman Empire mobilized about three million soldiers ${ }^{1}$ and its economic and military resources for the First World War. Many soldiers fought to survive on the distant fronts from their hometowns, but their efforts did not ensure victory in the end despite the significant successes in Dardanelles and Kut. Even worse, the Great War meant demographic devastation to the Ottomans. Contagious diseases such as tuberculosis and the Spanish Flu led to large-scale deaths across the country. Despite the lack of accurate numbers, it is widely accepted that the number of casualties Ottomans suffered was extremely high ${ }^{2}$ compared with the members of the Allied Powers and that of the Central Powers. While the vast majority of the Ottoman soldiers fought to survive in the mentally and physically harsh conditions of the trenches, hundreds of thousands of Ottoman soldiers, including deaths resulting from epidemic diseases, died during the war. Both the Ottoman army ${ }^{3}$ and the British army ${ }^{4}$ calculated the total number of deaths as 325,000 . According to Hikmet Özdemir, who carried out extensive research on the deaths in the Ottoman war theatres, estimated the number of war and disease-related deaths as 460,000. ${ }^{5}$ The armistice of Mudros (30 October 1918) was supposed to conclude the long-lasting conflict between the Allied Powers and the Ottoman Empire. Still, it can be interpreted as the harbinger of another stage of violence in Turkey that started with the Tripolitanian War (1911-1912) against Italy.

The armistice stipulated that the demobilization of the Ottoman armed forces except for the troops was needed for border security and public order. That is to say, a hundred thousand soldiers who managed to survive war violence and epidemic diseases would be allowed to return to prewar civilian life. Yet, the actual state on the ground was a bit different. The Ottoman General Staff sought to exploit the loopholes in the armistice of Mudros to demobilize fewer soldiers. ${ }^{6}$ A complete demobilization was not carried out $d e$ facto, and the Ottoman army was reorganized into nine corps and 20 divisions which included 61,223 rank and files after the armistice. ${ }^{7}$

1 Edward Erickson, Ordered to Die: A History of the Ottoman Army in the First World War, Westport-Connecticut, London, Greenwood Press, 2001, p. 208.

2 Erik Jan Zürcher, The Young Turk Legacy and Nation Building: From the Ottoman Empire to Atatürk's Turkey, London, New York, I. B. Tauris, 2010, p. 186.

3 Evgeniy Vasileviç Maslovskiy, General Maslofski'nin Umumî Harpte Kafkas Cephesi Eserinin Tenkidi, translated by Nazmi İlker, Ankara, Genelkurmay Matbaası, 1935, p. 48.

4 Hikmet Özdemir, The Ottoman Army 1914-1918: Disease and Death on the Battlefield, Salt Lake City, The University of Utah Press, 2008, p. 119.

5 Hikmet Özdemir, Disease and Death..., p. 121.

6 Türk Istiklâl Harbi I Mondros Mütarekesi ve Tatbikatı, Vol.1, Ankara, ATASE Yayınları, 1999, p. 263.

7 Türk Silahlı Kuvvetleri Tarihi Osmanlı Devri Birinci Dünya Harbi İdari Faaliyetler ve Lojistik, Vol.10, Ankara, ATASE Yayınları, 1985, p. 581. 
This study endeavors to concentrate on their demobilization experiences and re-adjustment to civilian life by enlightening their roles in the organization of resistance against the occupations taken up by the Allied Powers. The First World War seemed to have ended, but new exhaustive warfare hove into view. Many demobilized soldiers faced a painful dilemma: keeping fighting or returning home. Post-war violence was not peculiar to Turkey because after the end of the war, violence went on in different corners of Europe, in particular "vanquished" countries. ${ }^{8}$ The First World War can be interpreted as "just the second stage of the 10-year war" for the Ottoman officers. ${ }^{9}$ More than four million people lost their lives due to the conflicts from 1918 to 1923. Neither the armistices nor treaties concluded the violence. Russia, the Baltic states, Poland, Austria, and Hungary experienced post-war violence. ${ }^{10}$ The Great War did not solve the prewar issues and brought about more political and military problems, making violence one of the most significant post-war European elements.

A conventional methodological problem arises while scrutinizing the demobilization process that the Ottomans carried out after the armistice. As the overwhelming majority of the Ottoman soldiers were illiterate and left no written sources behind them, extensive historical research into their social history seems like a tough job. However, senior and junior officers reported many sources, which were extremely helpful to learn their post-war experiences. Their diaries and memoirs were two of the most eligible sources to research their post-war lives and hear the soldiers' voices. Research on the social history of demobilized soldiers carried out with the help of the archival documents seems respectively insufficient. Unfortunately, as a result, the Ottoman officers are at the center of this study.

\section{The Process of Demobilization}

Many soldiers and civilians in the Ottoman Empire welcomed the Mudros Armistice, overlooking its harsh terms that would jeopardize its survival. However, this was because they were mentally and physically exhausted from the war and considered that the armistice would bring permanent peace. During the war, lots of soldiers fully expected

8 Robert Gerwarth, The Vanquished: Why the First World War Failed to End, New York, Farrar, Straus and Giroux, 2016.

9 Mesut Uyar, The Ottoman Army and the First World War, London, New York, Routledge, 2021, p. 418.

10 Richard Bessel, "Post-War Societies", 1914-1918 Online: International Encyclopedia of the First World War, ed. by Ute Daniel, Peter Gatrell, Oliver Janz, Heather Jones, Jennifer Keene, Alan Kramer, Bill Nasson, Berlin, p. 10, December 5 , 2017 (Online), https://encyclopedia.1914-1918-online.net/pdf/1914-1918-Online-post-war_societies-2017-12-05.pdf, 4 February 2021. 
the peace treaty ${ }^{11}$ that would conclude the long-lasting and destructive warfare and enabled them to return to prewar civilian lives. However, some Ottoman military and bureaucratic members were worried about the specific terms of the armistice ${ }^{12}$ (especially the seventh and twenty-fourth terms) since the Ottoman territorial integrity was under a terrible danger of foreign occupations, and even its partition was probable.

After the signing of the Mudros Armistice, the Ottoman government issued a regulation (Terhis Talimâtnamesi) to demobilize the soldiers. ${ }^{13}$ Still, its application was somewhat different from what the Ottoman statesmen and the Allied Powers' representatives anticipated at the beginning. An immediate demobilization of the soldiers that the armistice stipulated meant the lack of labor and general security problems. During the Great War, some Ottoman army men were not combatants since they were employed in various sectors of the government and economy. One of the thorny problems the Ottoman Empire had to solve during the Great War was the workforce deficit which was alleviated with enlisted persons. Following the armistice, many soldiers were not demobilized as they were employed in state administration like courts, ${ }^{14}$ agricultural production and salt manufacture. ${ }^{15}$ Thus, the Ottoman government decided to pay a kind of monetary reward (mükâfât-i nakdîye) to stifle the increasing discontent among the non-demobilized soldiers at forced labor. ${ }^{16}$

Some high-ranking officers deliberately stemmed from demobilization, a point to which the Allied Powers devoted close attention. Furthermore, the Ottoman army suffered from the problem of a large number of deserters, many of which committed

11 İ. Hakkı Sunata, Gelibolu'dan Kafkaslara: I. Dünya Savaşı Anılarım, İstanbul, Türkiye İş Bankası Kültür Yayınları, 2008, p. 447; Abidin Ege, Çanakkale, Irak ve Iran Cephelerinden Harp Günlükleri, prepared by Celali Y1lmaz, İstanbul, Türkiye İş Bankası Kültür Yayınları, 2010, p. 489; Halil Ataman, Harp ve Esaret, prepared by Ferhat Ecer, İstanbul, Türkiye İş Bankası Kültür Yayınları, 2011, p. 82; Avedis Cebeciyan, Bir Ermeni Subayın Çanakkale ve Doğu Cephesi Günlüğ̈̈ 1914-1918, ed. by Rober Koptaş, translated by Takuhi Tomasyan, İstanbul, Aras Yayınc1lik, 2015, p. 147; M. Şevki Yazman, Kumandanım Galiçya Ne Tarafa Düşer?, İstanbul, Türkiye İş Bankası Kültür Yayınları, 2006, p. 268; Mehmet Oral, Hicaz Çöllerinde Bir Avuç Türkün Kahramanlı̆̆l: Kafkas, Hicaz ve Esaret Anıları, Konya: Kömen Yayınları, 2011, p. 143; İhsan Ulvi Efendi, Birinci Dünya Savaşından Kurtuluşs Savaşına Bir Subayın Günlükleri, prepared by İhsan İplikçioğlu, Ömer Yıldırım, Ankara, Kültür Ajans Yayınları, 2017, p. 45-46; Esat Arslan, Musullu Abdülhadi'nin İzinde: Bozgundan Zafere, Ankara, Phoenix Yayınları, 2005, p. 120; Güliz Beşe Erginsoy, Dedem Hüseyin Atıf Beşe: Bir Cemiyet-i Osmaniye Askerinin Savaş Hatıratı ve Bir Türkiye Cumhuriyeti Vatandaşının Yaşam Öyküsü, İstanbul, Varlık Yayınları, 2004, p. 198.

12 Fahri Belen, Askeri, Siyasal ve Sosyal Yönleriyle Türk Kurtuluş Savaşı, Ankara, Başbakanlık Basımevi, 1973, p. 16-17.

13 T.C. Cumhurbaşkanlı̆̆ Devlet Arşivleri Başkanlığı Osmanlı Arşivi (BOA), Dahiliye Nezâreti İdâre-i Umumiye (DH.I.UM.) 4/3-9, 18 Rebiülâhire 1337 (21 Haziran 1919).

14 BOA, DH.I.UM., 19/1-2, 18 Rebiülevvel 1337 (22 Aralık 1918).

15 BOA, Dahiliye Nezâreti Mebânî-i Emirîye ve Hapishâneler Müdüriyeti (DH.MB.HPS.), 109/27-2, 7 Cumâdelâhire 1337 (10 Mart 1919).

16 BOA, Bâb-ı Âlî Evrak Odası (BEO), 4624/346794-3, 29 Kânûn-1 Sânî 1336 (29 Ocak 1920). 
brigandage as a means of livelihood with the "rifle and ammunition" that they stole from the Ottoman army, ${ }^{17}$ resulting in social and economic instability for local inhabitants in various parts of Anatolia. The desertion issue was examined with the brigandage of Ottoman archival documents as if they were "synonymous". The most optimum means of livelihood for deserters was such an illegal act. ${ }^{18}$

In addition to economic and security-related concerns, some Ottoman commanders procrastinated the demobilization. For example, Ali İhsan (Sabis) Pasha wished not to disarrange the troops under his command because he planned to resist against the occupations of the vilâyât-1 site and thought that demobilization might inflict casualty on the forces in harsh winter conditions. ${ }^{19}$ After arriving in Istanbul on 3 March 1919, Ali İhsan was arrested and went into exile in Malta. He had helped the local Powers in Urfa to organize against the occupations of the Allied Powers after the armistice and arrested an English lieutenant colonel named Kelling. ${ }^{20}$ Moreover, Fahreddin (Türkkan) Pasha, the commander of troops defending Medina and Mecca and called "Tiger of the Desert", kept fighting until January 1919. ${ }^{21}$ Yakup Şevki Pasha, who was the commander of the Ottoman $9^{\text {th }}$ army in Erzurum, was accused of encouraging the establishment of local organizations and military assistance to the local inhabitants of the Eastern Anatolia. ${ }^{22}$ In addition, Mustafa Kemal, who became the commander of the Y1ldirım (Thunderbolt) Army Group on 31 October 1918, was worried with regards to the imminent dangers that the armistice engendered as its articles were open to dispute. ${ }^{23}$ Nihat Pasha (Anılmış), Galip Pasha (the commander of the 40th division in Yemen), and Tevfik Pasha (the commander of the 7th corps in Yemen) were blacklisted by the British high commissioner in Istanbul because of so-called war crimes or the violation of the armistice. Of those who went into exile on Malta island, there were many leading commanders who fought in the Great War. The British high commissioner launched a massive manhunt in Istanbul with the help of the Ottoman government and the Sultan, who wished to purge the army and bureaucracy of the Committee of Union and Progress. ${ }^{24}$

17 Ahmed Emin, Turkey in the World War, New Haven, Yale University Press, 1930, p. 262.

18 Mehmet Beşikçi, The Ottoman Mobilization of Manpower in the First World War: Between Voluntarism and Resistance, Leiden, Boston, Brill, 2012, p. 268-269.

19 Ali İhsan Sabis, Harp Hatıralarım, Vol.4, Istanbul, Nehir Yayınları, 1991, p. 326.

20 Ali İhsan Sabis, Harp Hatıralarım..., p. 328-329.

21 S. Tanvir Wasti, “The Defence of Medina, 1916-19”, Middle Eastern Studies, Vol.XXVII, No.4, 1991, p. 642, (Online), http://www.jstor.org/stable/4283467, 16 December 2020.

22 Selma Yel, "Mondros Mütarekesi ve İngiliz Politikası”, Atatürk Yolu Dergisi, Vol.VIII, No.2, 1991, p. 723.

23 Türk İstiklâl Harbi I: Mondros Mütarekesi ve Tatbikatı, Ankara, Genelkurmay ATASE Yayınları, 1999, p. 64.

24 Bilal N. Şimşir, Malta Sürgünleri, Ankara, Bilgi Yayınevi, 1985, p. 34-35. 
A specific part of Ottoman high-ranking military officers preferred clandestinely to keep the ablest officers that constituted the army's backbone, considering that their absence would bring about more organizational and functional impairment in the military. While reorganizing the remaining troops from the war, 2,500 officers whose score of military service seemed the highest were ascertained to keep working for the Ottoman army. ${ }^{25}$ As disarming the Ottomans was one of focal points of the armistice, Great Britain kept that process under close surveillance. ${ }^{26}$ The British army knew the risks involved with the armed forces that could make the occupations hard and pave the way for a dire resistance movement. As the Allied Powers seemed to have been worried about a probable revolt in the future, they demanded an immediate demobilization of the military manpower. ${ }^{27}$ The soldiers realized their dream of returning home.

Despite the procrastination above of immediate demobilization and its uneven application, the number of Ottoman army soldiers decreased dramatically by one-third while it was 337,000 on 30 October $1918 .{ }^{28}$ Nevertheless, the army's core remained respectively active, and there was not a total breakdown in "the chain of command" after the demobilization. Despite the lack of large-scale revolt by the Ottoman soldiers in the war, the high number of deserters, approximately $500,000^{29}$ can be interpreted as a sign of the widespread discontent at the battle. Thus, the lack of this kind of revolt cannot be evidence of military cohesion because many Ottoman soldiers expressed their point of view through mass desertion, but not a mass revolt.s

\section{Returning Home}

The demobilization process proved troublesome because of the transportation and ration of food, a frequent and chronic problem during the war. In particular, the Ottoman Empire's transportation infrastructure had been insufficient for military logistics during the war. Underdeveloped "transport facilities", overloaded rail lines, inadequate number of locomotives, etc., were "the biggest problem of all". ${ }^{30}$ Their homecoming was seriously interrupted due to the lack of means of transportation, but there was another

25 Zekeriya Türkmen, Mütareke Döneminde Ordunun Durumu ve Yeniden Yapılandırılması, Ankara, Türk Tarih Kurumu Yayınevi, 2001, p. 82.

26 Briton Cooper Busch, Mudros to Lausanne: Britain's Frontier in West Asia, 1918-1923, Albany, State University of New York, 1976, p. 64.

27 Ahmed Emin Yalman, Yakın Tarihte Gördüklerim ve Geçirdiklerim, prepared by Erol Şadi Erdinç, İstanbul, Pera, 1997, p. 445 .

28 Zekeriya Türkmen, Mütarake Döneminde..., p. 35.

29 Edward Erickson, Ordered to Die..., p. 211.

30 Erik Jan Zürcher, The Young Turk Legacy..., p. 182-183. 
substantial risk for the demobilized soldiers. They were under the attack of brigands, some of whom had deserted from the army, across Anatolia. Their ex-comrades looted the soldiers who fought with determination and survived the war. ${ }^{31}$ It was apparent that deserters were a direct threat to the public order in the Ottoman rural areas. Several transit points, such as Pozant1 where some accommodation can be arranged for demobilized soldiers, were occupied because of their strategic importance by the Allied Powers. ${ }^{32}$ Admiral R. D. Robeck, the British High Commissioner in Istanbul, often pressed the Ottoman officials for an immediate demobilization process. By March 1919, 337,000 men were demobilized..$^{33}$

Many of the demobilized soldiers were transported to Istanbul, from where they would be sent to their hometowns. They suffered from bad accommodation, were poorly dressed up and were poorly fed similar to conditions of war $^{34}$ and the lives of homeless people in today's big cities. Rauf (Orbay), who signed the armistice of Mudros on behalf of the Ottoman government, complained about the living conditions of the demobilized soldiers in Istanbul when he met Damat Ferit Pasha, the Grand Vizier of the Ottoman Empire. He expostulated with him, saying that:

"The government has to send the demobilized soldiers to their hometowns. You are not doing that, leaving them in misery. Men left the mess, barrack, don't have bread, a roof over their heads. They wander in the streets in a needy way. I saw foreigners dole out money to them in Toptaşm [sic] with my own eyes. They are neither Unionist nor Accords. They performed their national services by running around from one front to another front, wallowing in the firing line, did not die. However, at the moment, they were forced to live in misery. Such circumstances lead to a general uprising". ${ }^{35}$

Given that the Ottoman government's capacity to send the veterans to their homes was insufficient, they had to find alternative ways to reunite with their families. Many of them arranged transport facilities by paying from their own pockets. ${ }^{36}$ Even in Istanbul, the state authority and ability to carry out demobilization in an effective way

31 BOA, BEO, 4552/341348, 18 Kânûn-1 Sânî 1335 (18 Kasım 1919).

32 Türk Istiklâl Harbi I: Mondros Mütarekesi ve Tatbikatı, Ankara, Genelkurmay ATASE Yayınları, 1999, p. 93.

33 Istiklal Harbi..., 272-273.

34 BOA, BEO, 4549/341104-2, 26 Kânûn-1 Evvel 1334 (26 Aralık 1918).

35 "Hükümet terhis ettiği askerleri memleketlerine kadar sevketmeğe mecburdur. Siz bunu yapmiyor, hepsini perişan bir vaziyette bırakıyorsunuz. Adam, karavanadan, kışladan ayrılmış, yiyecek ekmeği, barınacak çatısı yok. Aç ve bîilâç, sokaklarda dolaşıyor. Ben, Toptaşmda [sic] yabancıların bunlara sadaka verdiklerini gözlerimle gördüm. Bunlar ne İttihatçı, ne İtilâfçı... Cepheden cepheye koşarak ateşler içinde yüzerek, vatana karşı olan borçlarını ödemişler, ölmemişler... Ama şimdi, ölümden beter bir sefaletle mahkûm edilmektedirler... İşte bu gibi haller, mutlaka umumî bir kıyama yol açar...". Rauf Orbay, Cehennem Değirmeni: Siyasî Hatıralarım, İstanbul, Emre Yayınları, 1993, p. 237.

36 BOA, DH.I.UM. 4-2/3-5, 13 Rebiülevvel 1337 (17 Aralık 1918). 
was undermined. The Ottoman Empire decided to pay salary to the reserve officers for three months after the demobilization to manage on for a short time. ${ }^{37}$

Among the demobilized soldiers, including officers, there was a collective mood of physical and mental exhaustion and pessimism in the aftermath of the war. ${ }^{38}$ The world fell into social and cultural depression, and many people questioned their religious beliefs. Due to the extreme brutality and high mortality in the warfare between 1914-1918, God's role was examined. Psychology pushed sociology into the background since individuals underwent a range of psychological destruction. ${ }^{39}$ High-ranking officers like Kazım (Karabekir) Pasha, who would be appointed as the commander of the $15^{\text {th }}$ corps of the Ottoman army, looked utterly hopeless about their future and even considered resignation from the military. ${ }^{40}$ The war brought about such severe mental disorders that soldiers needed a long time to adapt to civilian life. Nearly all of the belligerent countries' soldiers in the First World War had the same problems: re-adaptation into civil life, and getting rid of "physical, psychological and emotional strains from the war". ${ }^{41}$ There is an essential point to stress: those who lost the war quickly demobilized their armies because of their armistices' obligations. Their capacity to demobilize hundreds of soldiers and "re-integrate" them into social life in a well-organized way was respectively limited. ${ }^{42}$ Veterans all over Europe waited for the materialization of their expectations about the post-war order. They believed that as they put their lives in danger for their nations, they expected "material benefits" and great "opportunities". When the post-war societies' political, economic, and social realities did not live up to their expectations, the results were "anger and disillusionment" ${ }^{43}$ In particular, the Ottoman Empire's capacity to integrate veterans into civilian life was considerably limited because of the deterioration in politics and economy. Thus, the Ottoman ex-servicemen had to save themselves and stand on their own feet rather than on the Ottoman government's reliefs.

37 İ. Hakkı Sunata, Istanbul'da İsgal Yılları, İstanbul, Türkiye İş Bankası Kültür Yayınları, 2006, p. 14.

38 Ahmed Emin Yalman, Yakın Tarihte Gördüklerim..., p. 446; Fahrettin Altay, 10 Yıl Savaş ve Sonrast..., Ankara, Evren Yayınları, 2008, p. 173-176; İ. Hakkı Sunata, Istanbul'da Işsgal..., p. 11.

39 Zafer Toprak, Türkiye'de Yeni Hayat: İkılap ve Travma 1908-1928, İstanbul, Doğan Kitap, 2017, p. 14.

40 Kâzım Karabekir, İstiklal Harbimiz, Vol.1, İstanbul, Emre Yayınları, 2000, p. 88.

41 Julia Eichenberg, "Veterans' Associations", 1914-1918 Online: International Encyclopedia of the First World War, ed. by Ute Daniel, Peter Gatrell, Oliver Janz, Heather Jones, Jennifer Keene, Alan Kramer, Bill Nasson, Berlin, p. 3, October 8, 2014 (Online), https://encyclopedia.1914-1918-online.net/pdf/1914-1918-Online-veterans associations-2014-10-08.pdf, 12 September 2020.

42 Richard Bessel, "Post-War Societies...", p. 3.

43 James M. Diehl, "Demobilization and Discontent", A Companion to Europe, ed. by Gordon Martel, Oxford, Malden, Blackwell Publishing, 2006, p. 287. 
Many ex-soldiers looked for ways to set their lives in order by seeking a job in Istanbul and other cities even though the Ottoman government followed a benevolent but insufficient and weak policy for the veterans. ${ }^{44}$ They had to make a living the hard way, but the economy deteriorated dramatically during the war, and Ottoman women entered the labor market in remarkable numbers. As men were enlisted in the army, the labor gap was filled by women. In the aftermath of the Great War, many women preferred to remain in the "labor force" rather than return to their traditional roles. Women were more "assertive and visible" in public spaces. Ex-soldiers were confused about "post-war gender roles". ${ }^{45}$ Because of the mass unemployment after the war, some of the ex-soldiers professed to be a porter ${ }^{46}$ and many went around begging, as mentioned above. ${ }^{47}$ Ex-soldiers who took up business had serious difficulty staying afloat due to their lack of know-how in commerce. While readjusting to civilian life, ex-soldiers deploringly questioned the causes of the First World War. ${ }^{48}$ The Allied Powers' decisive victory and their presence in Istanbul seems to have made them upset and consider the war meaningless and futile for themselves.

Having a job in government services or law enforcement departments could be interpreted as an optimum way to earn their bread. Lots of veterans tried to seek a career in this field, ${ }^{49}$ but many of them failed. Needless to say, as the Ottoman government could not perform essential state services, and there was a significant absence of order in public space across the empire, holding a job in public service with low pay, and minor benefits was both a discouraging and onerous duty. ${ }^{50}$ While many ex-soldiers returned to their villages and looked for jobs in cities, those who dropped out of schools because of the war wished to continue their education. ${ }^{51}$ In addition to these ex-soldiers, some of the Ottoman prisoners of war (POW) chose to readjust to civilian life through educational institutions, forgetting the Great War's tragic memories. ${ }^{52}$

44 Mehmet Beşikçi, “İhtiyat Zâbiti”nden "Yedek Subay”a: Osmanlı'dan Cumhuriyet'e Bir Zorunlu Askerlik Kategorisi Olarak Yedek Subaylik ve Yedek Subaylar, 1891-1930”, Tarih ve Toplum, No.13, 2011, p. 68.

45 James M. Diehl, “Demobilization and Discontent...”, p. 280.

46 İ. Hakk1 Sunata, Gelibolu'dan Kafkaslara ..., p. 603.

47 Rauf Orbay, Cehennem Değirmeni..., p. 237.

48 Faik Tonguç, Birinci Dünya Savaşı'nda Bir Yedek Subayın Anıları, İstanbul, Türkiye İş Bankası Kültür Yayınları, 2008, p. 313-316.

49 BOA, BEO, 4654/349006-1, 22 Eylül 1336 (22 Eylül 1920); BOA, DH.MB.HPS., 46/8-1, 19 Şaban 1339 (28 Nisan 1921).

50 Faik Tonguç, Birinci Dünya Savaşı'nda..., p. 316.

51 BOA, Meclis-i Vükelâ (MV.) 221/94-1, 12 Recep 1339 (22 Mart 1921).

52 M. Fuad Tokad, Kibrit Kutusundaki Sarıkamış Sibirya Günlükleri, prepared by Jack Snowden, İstanbul, Timaş, 2011, p. 283. 
In contrast, others preferred to join the resistance movement in Anatolia. The Ottoman prisoners in Russia did not keep aloof themselves from current issues in Ottoman politics and pondered them while being detained in various camps across Russia. ${ }^{53}$ Captivity experience provided them an ample opportunity to think about such matters. The ex-combatants of the war seem to have accepted the decisive defeat and made a tremendous effort to get their lives in order. The Ottoman POWs, who were repatriated after the armistice, were considered qualified workforce by retired and active officers who sought to encourage them to participate in the National Forces (Kuva-y1 Milliye). ${ }^{54}$ Great Britain deliberately procrastinated the process of repatriation and spread propaganda against the Ankara government. ${ }^{55}$ The Greek army in Anatolia prevented the repatriated POWs passing across zones that the Greek army occupied. ${ }^{56}$

\section{Re-Organization of Ottoman Ex-Officers}

After the respective demobilization of the Ottoman army, some of the ex-officers were organized to defend their interests. Due to the mass mobilization in the Great War, veterans formed a new social group, veterans. They became a distinctive political actor in the post-war political and social structure. "Disability treatment, rehabilitation, and pension" were vital care for veterans. In prewar times, charities provided services to them, but many invalids required more organized and efficient service for their treatment. There was a "contract" which showed that the government had to look after invalids if they fought for the country. ${ }^{57}$ However, due to the lack of state-led initiatives in readjusting ex-combatants into civilian lives, the ex-officers' societies helped them act in a more organized way. The severe conditions of the post-war society fostered a natural sense of solidarity among the Ottoman veterans. As they sought to cope with the harsh conditions in trenches and survive with their comrades, some stood shoulder to shoulder to hold on to life in the post-war era.

After the demobilization, there were two significant societies established by the Ottoman ex-reserve officers, namely, the Aid Society of Reserve Officers (İhtiyât Zâbitleri Teâvün Cemiyeti) and the Ottoman Society of Reserve Officers (Osmanlı

53 Yücel Yanıkdağ, Healing the Nation: Prisoners of War, Medicine and Nationalism in Turkey, 1914-1939, Edinburgh, Edinburgh University Press, 2014, p. 85.

54 BOA, Dahiliye Nezareti İdare-i Umumiye Ekleri (DH.I.UM.EK.), 118/73-1, 4 Cumâdelâhire 1338 (24 Şubat 1920).

55 Cemalettin Taşkıran, Ana Ben Ölmedim: I. Dünya Savaşı'nda Türk Esirleri, İstanbul, Türkiye İş Bankası Kültür Yayınları, 2008, p. 334-338.

56 BOA, Hariciye Nezareti Siyasi (HR.SYS.), 2566/5-56, 26 Haziran 1920.

57 James M. Diehl, “Demobilization and Discontent...”, p. 282. 
İhtiyât Zâbitan Cemiyeti). The Ottoman men who fought in the Great War had no" sociological" basis for founding such societies ${ }^{58}$ and many returned to their villages. Some members of the former community were the students of Darülfünun (Ottoman university in Istanbul). They mainly demanded to be employed by the government and for continuation of their education in this educational institution. To make their voices heard, they published a periodical named the Post of Reserve Officers (İhtiyât Zâbitleri Postas1). ${ }^{59}$ They got involved in pursuing economic rights and policies that promoted the veterans' re-integration into the post-war society. This newspaper served to bring public attention to the issue of demobilized soldiers. Ottoman reserve officers wrote an open letter to the Ottoman war minister, stressing that the Ottoman ex-officers were devoid of basic daily necessities in a desperate need even though they had performed their national duties during the Great War. ${ }^{60}$ They posted the job seeker's occupational qualifications on some pages so that unemployed ex-officers could be placed in employment. ${ }^{61}$ What is more, they established a company whose capital was raised by the Aid Society of Reserve Officers' members. ${ }^{62}$ Of the ex-reserve officers of the Ottoman army, the disabled ones suffered the post-war problems at most. ${ }^{63}$

The other society established by the reserve officers who had fought in the war was the Ottoman Society of Reserve Officers (Osmanlı İhtiyât Zâbitan Cemiyeti), which had a close relationship with the Ottoman government. At the same time, the Aid Society of Reserve Officers was believed to be pro-Unionist groups. The attitude of these societies to the resistance movements against the Allied occupations in Anatolia significantly varied. The Committee of Union and Progress was politically and socially discredited as it was held responsible for wartime sufferings such as high inflation, famine, poverty, deaths, and defeat. While the societies above were established to foster a sense of solidarity among the ex-reserve officers, its members tended to support the resistance movements against the Allied Powers' occupations. There were many such societies across Anatolia at the local level, but they lacked connection and hierarchical structure. What made these officers come together were the re-adjustment problems of the postwar society and the country's political and military debacle. ${ }^{64}$

58 Mehmet Beşikçi, “İhtiyat Zâbiti”nden "Yedek Subay”a...", p. 69-70.

59 Ali Servet Öncü, “İstanbul'da Mütarake Dönemi Yedek Subay Teşkilatlanmaları”, Atatürk Üniversitesi Türkiyat Araştırmaları Enstitüsü, No.40, 2009, p. 344.

60 Ihtiyât Zâbitleri Postası, No.1, 3 Kânûn-1 Evvel 1334 (30 Aralık 1918), p. 2-3.

61 İhtiyât Zâbitleri Postast, No.2, 1334, p. 1-4.

62 Ihtiyât Zâbitleri Postast, No.6, 3 Şubat 1335 (3 Şubat 1919), p. 3.

63 Ihtiyât Zâbitleri Postası, No.8, 20 Şubat 1335 (20 Şubat 1919), p. 1.

64 Mehmet Beşikçi, "İhtiyat Zâbiti”nden "Yedek Subaya...”, p. 72-73. 


\section{Participation in the Resistance Movements}

Despite the collective sense of comfort derived from the Mudros Armistice, its application and occupations (Mosul, Alexandretta, İzmir), which were believed to harm the entire empire's existence, provoked anger among the Ottoman officers. In particular, "high-ranking officers" of the Ottoman Empire figured out that enemies were disrespectful of the articles in Mudros. ${ }^{65}$ The fifth article of the armistice demanded the immediate demobilization of the entire Ottoman army except for the units who were responsible for the internal security and the protection of the borders. The ceasefire brought about disappointment and anger rather than the peace that many Ottomans wished. The Allied powers maintained the occupations in Anatolia and did not abstain from abusing the seventh article of the armistice. ${ }^{66}$ The flotillas of Great Britain, France, and Italy officially laid alongside the capital city, Istanbul, on 13 November 1918. The British army occupied Mosul 15 days after the armistice while the major cities in Anatolia such as Antalya, Adana, and Maraş suffered the same fate ${ }^{67}$ In particular, the unexpected occupation of Izmir in May 1919 was politically shocking and painful for the Ottomans who remembered the loss of the Balkans in lament. ${ }^{68}$

However, the birth of resistance movements did not start with that occupation. ${ }^{69}$ Instead, it triggered a solid popular opinion. The ex-soldiers who tenaciously fought to death to save their country and family had an offending post-war experience when they encountered the Allied soldiers in Istanbul. Also, the Greek army was deployed in Istanbul, although the Ottoman army was not at war with it. Greek soldiers' presence politically and militarily caused a pang of sorrow because Greece had been under the sovereignty of the Ottoman Empire for approximately four hundred years. The Allies occupied the heart of the empire. ${ }^{70}$ Some of the demobilized ex-reserve officers joined the rallies against the occupations..$^{71}$ They were even little active members of the postwar Ottoman political structure and did not isolate themselves from the post-war society. The Great War ended in a crushing defeat for the Ottomans, leading to the eventual

65 A. L. Macfie, The End of the Ottoman Empire, 1908-1923, New York, Routledge, 1998, p. 307.

66 The Allies to have the right to occupy any strategic points in the event of any situation arising which threatens the security of the Allies.

67 Baskın Oran, Türk Dış Politikası: Kurtuluş Savaşından Bugüne Olgular, Belgeler, Yorumlar, İstanbul, İletişim Yayınları, 2009, p. 112.

68 Zekeriya Türkmen, Mütareke Döneminde..., p. 165.

69 Nur Bilge Criss, Istanbul Under Allied Occupation, Leiden, Brill, 1999, p. xii.

70 Doğu Ergil, Milli Mücadelenin Sosyal Tarihi, Ankara, Turhan Kitabevi, 1981, p. 42; Kâzım Karabekir, Istiklal Harbimiz..., p. 87.

71 Ali Servet Öncü, “İstanbul'da Mütarake Dönemi...”, p. 347-348. 
break-up of the Empire. In fact, "the existing political, social and cultural order" in the defeated countries lost their legitimacy. It is noteworthy that the worldwide cycle of post-war violence was an "exception" but not a universal fact. ${ }^{72}$ To understand the postwar violence, the demobilized soldiers' mindset in the defeated countries like the Ottoman Empire and Austria-Hungary is a significant point.

Many ex-officers played a leading role in constituting a national resistance movement against the Allied Powers. While soldiers were demobilized, some of them took their weapons and bullets home. ${ }^{73}$ Many of the high-ranking officers of the Ottoman army were unwilling to demobilize their troops and to surrender. Fahrettin (Altay) Pasha, a high-ranking military officer during the Great War, confessed that he had preferred to conceal the weapons and ammunition in mosques and madrasa in Konya, a central Anatolian city, instead of laying them down. ${ }^{74}$ Also, Kâzım Pasha and Mustafa Kemal, the leading figures of the Turkish Independence War, thoroughly expostulated the Ottoman Empire's disarmament. ${ }^{75}$

Some demobilized soldiers joined the Turkish army to fight against the Greek army, while others abstained from a new war. Some of the demobilized soldiers were sedated towards the resistance movements related to their public image and chance of success. The members of local societies like İzmir Rejection of Annexation Society (İzmir Redd-i İlhak Cemiyeti) included ex-Unionist members who stayed in power despite the dissolution of their political parties in 1918. Turkish national societies founded for resisting the occupations were mainly the outcome of literate persons, leading local figures, self-employed people (physician, lawyer, journalist, etc.), landlords, veterans, and senior Ottoman officers. There was a "natural" alliance between civilians and soldiers (veterans or active soldiers). ${ }^{76}$ In spite of the significant role of the "middle class" in making the societies above, Ottoman soldiers (veterans or active soldiers) helped them turn into a nationwide movement.

Some Ottoman veterans considered the national resistance to be a political and military adventure that might spell another terrible disaster after the Great War. ${ }^{77}$

72 Mark Edele-Robert Gerwarth, "The Limits of Demobilization: Global Perspectives on the Aftermath of the Great War", Journal of Contemporary History, Vol.L, No.1, 2015, p. 9-11.

73 Zekeriya Sertel, Hatırladıklarım, İstanbul, Remzi Kitabevi, 2001, p. 75; İ. Hakk1 Sunata, İstanbul'da İsgal..., p. 14.

74 Fahrettin Altay, 10 Yıl Savaş ve Sonrası, Ankara, Evren Yayınları, 2008, p. 171.

75 Stanford J. Shaw-Ezel Kural Shaw, History of the Ottoman Empire and Modern Turkey, Vol.2, Cambridge, Cambridge University Press, 2010, p. 340.

76 Doğu Ergil, Milli Mücadelenin ..., p. 47-48.

77 Ahmed Emin Yalman, Yakın Tarihte..., p. 437. 
Several inhabitants in Samsun suspected the military capacity of resistance movements, claiming that even though the Ottoman Empire fought with Germany and Austria-Hungary, it underwent a debacle. Thus, from their perspective, the National Struggle was condemned to fail due to its weak military and economic capacity. Furthermore, ex-deputies of the Ottoman parliament (Meclis-i Mebûsan) were invited to the procrastinated resistance movement to reply as they wished for its chance of success. ${ }^{78}$ The Ottoman grand vizier, Damat Ferit Pasha, called the deputies who sided with the National Struggle in Ankara as "rebels". ${ }^{79}$ The provision of economic and military support to the resistance was stigmatized as a criminal act by the Ottoman government. Mithat Şükrü (Bleda), one of the leading members of the Committee of Union and Progress, refused to participate in the National Struggle as he was exhausted from political turmoil and the First World War. He seemed to have been suspicious of its likelihood of military success. ${ }^{80}$

The cadre who put up a fierce resistance against the occupations of the Allied Powers in Anatolia were aware of the growing need for a standing army because of the military insufficiency of National Forces (Kuvâ-yı Milliye) that was established for armed resistance after the armistice. Thus, the Ankara government declared that the mobilization started with Ottoman entry into the war had been in full force and effect on 8 June 1920 . All ex-soldiers were supposed to obey that call and fight for the Ankara government, but not the Istanbul rule. The Ottoman veterans who fought to death needed to be re-enlisted again by compulsory military service. Those who refused to join the army of the Ankara government would be treated as a deserter. ${ }^{81}$ While raising a standing army, the Ankara government was confronted with a wide range of problems. Still, the most intractable one was the high rate of desertion, ${ }^{82}$ which left a detrimental impact on the Ottoman Empire's combat performance during the First World War. Military service was equal to death for many Ottomans because the army had the second-highest death rate in the Great War. ${ }^{83}$ According to the Turkish General Staff's official publication, of 325,000 deaths, 240,000 died of various contagious diseases such as typhus and dysentery. ${ }^{84}$ The

78 Faik Tonguç, Birinci Dünya Savaşı'nda..., p. 320.

79 Hasan Kayalı, "The Struggle for Independence", The Cambridge History of Turkey, Vol.4, ed. by Reşat Kasaba, Cambridge, Cambridge University Press, 2008, p. 116.

80 Mithat Şükrü Bleda, İmparatorluğun Çöküşü, İstanbul, Remzi Kitabevi, 1979, p. 153.

81 Mehmet Beşikçi, “İhtiyat Zâbiti”nden Yedek Subay”a...”, p. 75.

82 Doğu Ergil, Milli Mücadelenin ..., p. 220; According to Zürcher, the number of the deserters in the Ottoman army was about 500,000. See Erik Jan Zürcher, The Young Turk Legacy..., p. 186.

83 Stephen Broadberry-Mark Harrison, "Introduction...", p. 27.

84 Evgeniy Vasileviç Maslovskiy, General Maslofski'nin..., p. 48. 
chance of survival for the enlisted men was low compared with other belligerent countries, which made the military service unwelcome duty.

To make the enlisted soldiers discourage desertion and punish those who violated the call of remobilization, the Independence Tribunals (İstiklâl Mahkemeleri) inflicted immediate punishments for deserters and those who refused to participate in the army of the Ankara government. ${ }^{85}$ With the help of such a superior court, while the number of deserters was 30,809 in July 1921, it sharply decreased to 4,400 in August 1921, according to Asim Bey's report, the chief of staff at the Western Front. Many deserters were sent to the front line after receiving smooth punishment (hitting with a stick 40-100 times) rather than the death penalty since the tribunals sought to use the available workforce for the Turkish Liberation War as much as possible. ${ }^{86}$ As the Independence Tribunals were founded for punishing and executing the deserters, the cases concerning desertions loomed large in their workload. For instance, the tribunal in Kastamonu where many deserters and brigands absconded punished 420 people, 140 of whom were charged with desertion and desertion-related crimes like the encouragement of abandonment and hosting deserters. ${ }^{87}$ During the Great War, conscription was considered a practice that dramatically impaired the lives of conscripts and their families. ${ }^{88}$ The conscripts' wives and daughters were left unguarded and sexually assaulted when their father or husband was at the front. Such cases called indecent assault (fiil-i şenî) exist in abundance in the Ottoman archival documents. ${ }^{89}$

One reason why large numbers were unwilling to fight for the Ankara government was related to military barracks and living conditions on the fronts. Ottoman ex-soldiers did not forget their experiences of poor sanitation, poor diet/malnourishment, maltreatment and wearing worn out clothes. ${ }^{90}$ Conscription means "a tacit contract" between government and draftees. The former was supposed to provide necessities such as a good standard of nutrition, accommodation, medical services and to persuade them to fight in a "just war" and pull off a victory. ${ }^{91}$ The long duration of the First World War

85 Doğu Ergil, Milli Mücadelenin..., p. 231.

86 Ergün Aybars, İstiklal Mahkemeleri, Ankara, Ayraç, 2009, p. 139.

87 Ergün Aybars, Istiklal Mahkemeleri..., p. 89.

88 Yiğit Akın, When the War Came Home: The Ottomans' Great War and the Devastation of an Empire, Stanford, California, Stanford University Press, 2018, p. 29.

89 BOA, BEO, 4318/323828-1, 8 Zilhicce 1332 (28 Ekim 1914); BOA, Irade Harbiye (I.HB.) 176/28-2, 29 Zilhicce 1333 (7 Kasım 1915); BOA, I.HB. 176/65-2, 01-01-1334 (10 Kasım 1915); BOA, I.HB., 180/53-2, 4 Rebiülahire 1334 (9 Şubat 1916).

90 Doğu Ergil, Milli Mücadelenin..., p. 220.

91 Mehmet Beşikçi, The Ottoman Mobilization ..., p. 247. 
that almost no one predicted discouraged them from fighting for the so-called new military adventure. Four-year military experience taught that the war brought a debacle to both individuals and families. In particular, as there had been no breadwinners in many households during the Great War, social problems, such as poverty and prostitution went up. Many soldiers considered the war effort a futile attempt to survive the empire and prioritized themselves and their families in the face of economic and social hardships. The war eroded the credibility of the Ottoman Empire as a political unity in the eyes of its subjects. Both the Unionists and the empire themselves lost their legitimacy because of the crushing defeats and the harsh economic and human practices. ${ }^{92}$

\section{Conclusion}

The army veterans, in general, played a leading role in post war Europe and their wartime experience tremendously impacted their political activities by easing the acceptance of violence. Many of them participated in the fascist movement in Italy while some low-ranking juniors were quite annoyed by the Versailles Treaty and joined Freikorps. Post-war violence was an inseparable dimension of politics in not only Europe but also Turkey. The end of the Great War was a harbinger of another warfare for the Ottomans. The signing of the armistice of Mudros on 30 October 1918 did not conclude the cycle of the violence that the Ottoman Empire had been experiencing for long years. The immediate demobilization of the soldiers did not assure an efficient re-adjustment to civil life. After the armistice, approximately 300,000 soldiers were mentally and physically exhausted and would have to take care of themselves, demobilized. As the Ottoman Empire lacked economic resources and administrative tools, they founded a range of societies to defend their interests and assured a smooth transition to their civilian lives. The results of the armistice alarmed many senior and junior officers in the Ottoman Empire who thought that the occupations would jeopardize the empire's existence. Many ex-soldiers participated in the resistance movement, while others considered it to be a political and military adventure that the Unionist act embarked upon. Some soldiers, who had deserted from the Ottoman army and had been demobilized, participated in a new military struggle, and managed to achieve a victory that culminated with modern Turkey's independence. Even though the Ottoman veterans' approach to the resistance movement varied, their contributions to making a nation-state were significant. Despite their mental and physical exhaustion in the First World War, many of the demobilized soldiers were displeased with the postwar era's political and military course.

92 Yiğit Akın, When the War Came Home..., p. 10-11. 


\section{BIBLIOGRAPHY}

\section{Archival Sources ${ }^{93}$}

T.C. Cumhurbaşkanlı̆̆ı Devlet Arşsivleri Başkanlı̆̆ı Osmanlı Arşivi (BOA)

\section{Periodicals ${ }^{94}$}

\section{İhtiyât Zâbitleri Postası}

\section{Scientific Research Works}

Akın, Yiğit: When the War Came Home: The Ottomans' Great War and the Devastation of an Empire, Stanford, California, Stanford University Press, 2018.

Altay, Fahrettin: 10 Yll Savaş ve Sonrası, Ankara, Evren Yayınları, 2008.

Aybars, Ergün: İstiklal Mahkemeleri, Ankara, Ayraç, 2009.

Beşe Erginsoy, Güliz: Dedem Hüseyin Atıf Beşe: Bir Cemiyet-i Osmaniye Askerinin

Savaş Hatıratı ve Bir Türkiye Cumhuriyeti Vatandaşının Yaşam Öyküsü, İstanbul, Varlık Yayınları, 2004.

Beşikçi, Mehmet: "İhtiyat Zâbiti”nden "Yedek Subay”a: Osmanlı'dan Cumhuriyet'e Bir Zorunlu Askerlik Kategorisi Olarak Yedek Subaylık ve Yedek Subaylar, 1891-1930”, Tarih ve Toplum, No.13, 2011, p. 45-89.

Beşikçi, Mehmet: The Ottoman Mobilization of Manpower in the First World War:

Between Voluntarism and Resistance, Leiden, Boston, Brill, 2012.

Bleda, Mithat Şükrü: İmparatorluğun Çöküşü, İstanbul, Remzi Kitabevi, 1979.

Broadberry, Stephen-Harrison, Mark: "Introduction", The Economics of World War One, ed.

by Stephen Broadberry, Mark Harrison, Cambridge, Cambridge University Press, 2005.

Busch, Briton Cooper: Mudros to Lausanne: Britain's Frontier in West Asia, 1918-1923, Albany, State University of New York, 1976. 
Castillo, Jasen: Endurance and War: The National Sources of Military Cohesion, California, Stanford Security Studies, 2014.

Cebeciyan, Avedis: Bir Ermeni Subayın Çanakkale ve Doğu Cephesi Günlüğü 1914-1918, ed. by Rober Koptaş, translated by Takuhi Tomasyan, İstanbul, Aras Yayıncılık, 2015. Criss, Nur Bilge: Istanbul Under Allied Occupation, Leiden, Brill, 1999.

Diehl, James M.: "Demobilization and Discontent", A Companion to Europe, ed. by Gordon Martel, Oxford, Malden, Blackwell Publishing, 2006.

Edele, Mark-Gerwarth, Robert: "The Limits of Demobilization: Global Perspectives on the Aftermath of the Great War", Journal of Contemporary History, Vol.L, No.1, 2015, p. 3-14.

Ege, Abidin: Çanakkale, Irak ve Iran Cephelerinden Harp Günlükleri, ed. by Celali Yılmaz, İstanbul, Türkiye İş Bankası Kültür Yayınları, 2010.

Ergil, Doğu: Milli Mücadelenin Sosyal Tarihi, Ankara, Turhan Kitabevi, 1981.

Erickson, Edward: Ordered to Die: A History of the Ottoman Army in the First World War, Westport-Connecticut, London, Greenwood Press, 2001.

Gerwarth, Robert: The Vanquished: Why the First World War Failed to End, New York, Farrar, Straus and Giroux, 2016.

İhsan Ulvi Efendi: Birinci Dünya Savaşından Kurtuluş Savaşına Bir Subayın Günlükleri, prepared by İhsan İplikçioğlu, Ömer Yıldırım, Ankara, Kültür Ajans Yayınları, 2017. Karabekir, Kâzım: İstiklal Harbimiz. Vol.1, İstanbul, Emre Yayınları, 2000.

Kayal1, Hasan: "The Struggle For Independence", The Cambridge History of Turkey. Vol.4, ed. by Reşat Kasaba, Cambridge, Cambridge University Press, 2008.

Macfie, A. L: The End of the Ottoman Empire, 1908-1923, New York, Routledge, 1998. Maslovskiy, Evgeniy Vasileviç: General Maslofski’nin Umumî Harpte Kafkas Cephesi Eserinin Tenkidi, translated by Nazmi İlker, Ankara, Genelkurmay Matbaas1, 1935.

Oral, Mehmet: Hicaz Çöllerinde Bir Avuç Türkün Kahramanlı̆̆ı: Kafkas, Hicaz ve Esaret Anıları, Konya, Kömen Yayınları, 2011.

Oran, Baskın: Türk Dış Politikası: Kurtuluş Savaşından Bugüne Olgular, Belgeler, Yorumlar, İstanbul, İletişim Yayınları, 2009.

Orbay, Rauf: Cehennem Değirmeni: Siyasî Hatıralarım, İstanbul, Emre Yayınları, 1993. Öncü, Ali Servet: "İstanbul'da Mütarake Dönemi Yedek Subay Teşkilatlanmaları", Atatürk Üniversitesi Türkiyat Araştırmaları Enstitüsü, No.40, 2009, p. 341-355.

Özdemir, Hikmet: The Ottoman Army 1914-1918: Disease and Death on the Battlefield, Salt Lake City, The University of Utah Press, 2008.

Sabis, Ali İhsan: Harp Hatıralarım, Vol.4, İstanbul, Nehir Yayınları, 1991.

Sertel, Zekeriya: Hatırladıklarım, İstanbul, Remzi Kitabevi, 2001. 
Stanford J. Shaw-Kural Shaw, Ezel: History of the Ottoman Empire and Modern Turkey, Vol.2, Cambridge, Cambridge University Press, 2010.

Sunata, İ. Hakkı: Gelibolu'dan Kafkaslara: I. Dünya Savaşı Anılarım, İstanbul, Türkiye İş Bankası Kültür Yayınları, 2008.

Sunata, İ. Hakkı: İstanbul'da İşgal Yılları, İstanbul, Türkiye İş Bankası Kültür Yayınları, 2006. Şimşir, Bilal: Malta Sürgünleri, Ankara, Bilgi Yayınevi, 1985.

Taşkıran, Cemalettin: Ana Ben Ölmedim: I. Dünya Savaşı'nda Türk Esirleri, İstanbul, Türkiye İş Bankası Kültür Yayınları, 2008.

Tokad, M. Fuad: Kibrit Kutusundaki Sarıkamış Sibirya Günlükleri, prepared by Jack Snowden, İstanbul, Timaş, 2011.

Tonguç, Faik: Birinci Dünya Savaşı ’nda Bir Yedek Subayın Anıları, İstanbul, Türkiye İş Bankası Kültür Yayınları, 2008.

Toprak, Zafer: Türkiye'de Yeni Hayat: Inklap ve Travma 1908-1928, İstanbul, Doğan Kitap, 2017.

Türk Istiklâl Harbi I: Mondros Mütarekesi ve Tatbikatı, Ankara, Genelkurmay ATASE Yayınları, 1999.

Türk Silahlı Kuvvetleri Tarihi Osmanlı Devri Birinci Dünya Harbi İdari Faaliyetler ve Lojistik, Vol.10, Ankara, ATASE Yayınları, 1985.

Türkmen, Zekeriya: Mütareke Döneminde Ordunun Durumu ve Yeniden Yapılandırılması, Ankara, Türk Tarih Kurumu Yayınevi, 2001.

Uyar, Mesut: The Ottoman Army and the First World War, London, New York, Routledge, 2021.

Yanıkdağ, Yücel: Healing the Nation: Prisoners of War, Medicine and Nationalism in Turkey, 1914-1939, Edinburgh, Edinburgh University Press, 2014.

Yazman, M. Şevki: Kumandanım Galiçya Ne Tarafa Düşer?, İstanbul, Türkiye İş Bankası Kültür Yayınları, 2006.

Yel, Selma: "Mondros Mütarekesi ve İngiliz Politikası", Atatürk Yolu Dergisi, Vol.VIII, No.2, 1991, p.723-731.

Zürcher, Erik Jan: The Young Turk Legacy and Nation Building: From the Ottoman Empire to Atatürk's Turkey, London, New York, I. B. Tauris, 2010. 


\section{Online Sources}

Bessel, Richard: "Post-War Societies", 1914-1918 Online: International Encyclopedia of the First World War, ed. by Ute Daniel, Peter Gatrell, Oliver Janz, Heather Jones, Jennifer Keene, Alan Kramer, Bill Nasson, Berlin, December 5, 2017 (Online), https://encyclopedia.1914-1918-online.net/pdf/1914-1918-Online-post-war_ societies-2017-12-05.pdf, 4 February 2021.

Eichenberg, Julia: "Veterans' Associations", 1914-1918 Online: International Encyclopedia of the First World War, ed. by Ute Daniel, Peter Gatrell, Oliver Janz, Heather Jones, Jennifer Keene, Alan Kramer, Bill Nasson, Berlin, October 8, 2014 (Online), https://encyclopedia.1914-1918-online.net/pdf/1914-1918-Onlineveterans_associations-2014-10-08.pdf, 12 September 2020.

Wasti, S. Tanvir: "The Defence of Medina, 1916-19", Middle Eastern Studies, Vol. XXVII, No.4, 1991, (Online), http://www.jstor.org/stable/4283467, 16 December 2020 . 